\title{
Sintese da Formação de Nosso Espírito Municipal
}

\section{Yves DE Oliveira}

\author{
Diretor da Escola de Sociologia e Politica da Bahia
}

$\mathrm{N}$ Ão seria possivel estudar-se a atual doutrina municipalista sem uma análise dos antecedentes do que poderíamos chamar da Municipalidade brasileira. Mesmo que a Municipalidade brasileira só começasse a ter existência real com a Lei de $10^{\circ}$ de outubro de 1828 . Anteriormente a esta data, o Municipio em nosso País tinha as características administrativas de Portugal. Estávamos em pleno Brasil colonial e sob o império das leis e regulamentos portuguêses, que por sua vez tiveram origem nas leis romanas. A Municipalidade brasileira, no início, acumulava as funções administrativas e judiciárias.

No Brasil-Colônia o Municipio era regido pelas Ordenações Filipinas. Verificamos certas disposições as mais importantes tratadas referentemente ao Municipio pelo Código Filipino. No Título LXII, $\S 67$, relativamente às finanças das Municipalidades. Duas têrças partes das rendas eram destinadas às despesas do Conselho Municipal. Já no título LXV regulamentava o Conselho Municipal, e disciplinava as atribuições dos juizes ordinários. No Título LXV, $\S \S 22$ e 23 , dispunha sôbre os almotacês em face das atividades dos juizes ordinários. Nos $\S \S 73$ e 74 dêste Título, nós verificamos a regulamentação das atividades dos juizes das vintenas, isto é, que não tinham competência para julgar todos os crimes, e nas questões que não versavam sôbre bens de raiz. No Título LXVI, disciplinava as funções dos vereadores, os quais na linguagem da época eram os membros da Câmara, Cúria ou Assembléia do Município que o representavam, e administravam as rendas pelo regulamento de 30 de julho de 1591 . Essa corporação, também, se chamava Comuna, Conselho e Mesa de Vereação. A expressão Câmara significava, como ainda significa, a reunião dos vereadores. A corporação dos vereadores chamava-se Municipalidade. Com a Lei de $10^{\circ}$ de outubro de 1828 , a Municipalidade brasileira tornou-se uma corporação meramente administrativa, sem acumular mais as funções judiciárias.

No Título LXV, $\S \S 40$ e seg., regulava as fintas, processo usado para tôdas as aperturas e despesas extraordinárias, a que o Conselho se via obrigado. Regulava, por sua vez, as Ordenações, as taxas e despesas. No Titulo LXVI, de $1 .^{\circ}$, estabelecia que duas eram as reuniões semanais para a Câmara, às quartas-feiras e aos sábados. Nos Títulos LXVI a LXXI, tratava do tipo primitivo de organização da colônia, admitido pelo Código 
de D. Manoel, promulgado em 1521, quanto aí, ao modo de organização, competência e sistema eleitoral. No Título LXVII, $\S 60^{\circ}$, referente à chamada «eleição de barrete». No Título LXVII, § $80^{\circ}$, sôbre a confirmação da eleição do vereador. No Título LXXX, determinando que as funções do procurador são de caráter fiscalizante, embora ficasse ao cargo das rendas do Conselho. No Título LXX, estabelecendo as atribuições de um Tesoureiro, que exercia sua função em alguns conselhos. No Título LXXI, tratando das atividades do escrivão da Câmara. No Titulo LXXII, situava o escrivão da Almotaceria. No Título LXXIX § 29, referindo-se aos juizes ordinários, chamados também Juizes da terra.

Eram, em linhas gerais, as matérias importantes de caráter municipal, regulamentadas no Brasil-Colônia, pelo Código Filipino ou Ordenações do Reino de Portugal. Até aí, não poderemos afirmar que houvesse a doutrina municipalista, tal como se entende hoje, com o mesmo fundamento, que a informa no presente. Todavia, verificamos a plena revelação de um sentido municipal, de valorização da vida local, naquela época tão remota. Poderíamos afirmar sim, sem sombra de dúvida, que naquela época o Direito Municipal antecedeu ao Direito Constitucional brasileiro (Verificar, em complemento, o nosso «Curso de Direito Municipal»( $\left.{ }^{1}\right)$ a respeito, com o pensamento doutrinário do consagrado mestre, o saudoso Prof. Alcides GRECA, da Argentina).

\section{BRASIL REINO}

No Brasil-Reino, presenciamos uma decisão importante, a de $n .^{\circ} 37$, de 11 de setembro de 1817, na qual se declarava a maneira como deveriam se proceder nas câmaras, quando falecessem, ou fôssem substituidos os vereadores.

\section{A CONSTITUIÇÃO DO IMPÉRIO DE 1824}

1 - A 1.a Constituição Brasileira de 1824 - A independência do Brasil deu-se em 7 de setembro de 1822. A nossa organização lmunicipa regia-se pelas leis portuguêsas. Com a primeira Constituição Imperial de 25 de março de 1824 , traçando o arcabouço político e administrativo do país, as instituições municipais brasileiras começaram a ter um principio de regulamentação. A Constituição Imperial, nos seus arts. 167, 168 e 169, prescrevia:

«Art. 167. Em tôdas as cidades e vilas ora existentes nas mais, que para o futuro se criarem, haverá Câmaras, às quais compete o govêrno econômico e municipal das mesmas cidades e vilas».

Art. 168. As Câmaras serão eletivas e compostas do número de Vereadores que a Lei designar, e o que obtiver maior número de votos será o presidente.

(1) Curso de Direito Municipal - Livraria Freitas Bastos, Rio de Janeiro, 2.' edição 
Art. 169. O exercício de suas funções municipais, formação das suas posturas policiais, aplicação das suas rendas e tôdas as suas particulares e úteis atribuições, serão decretadas por Lei regulamentar».

José Antônio Pimenta Bueno em 1857, conceitua $\left({ }^{2}\right)$ «A população de cada cidade, vila ou municipio forma, pela natureza das coisas, uma sociedade especial, uma existência particular e própria, uma unidade, uma congregação de indivíduos que faz sim parte do Estado, mas que tem seus direitos próprios, suas idéias comuns, suas necessidades análogas e seus interêsses idênticos que demandam regulamentos apropriados às suas índoles e especialidades».

Assinala Joaquim Pires Machado Portela que os textos dos arts. 167 e 168 da Constituição do Império do Brasil foram cópias fiéis da Constituição Portuguêsa de 1821. $\left({ }^{3}\right)$

\section{A LEI MUNICIPAL DE $10^{\circ}$ DE OUTUBRO DE 1828}

Os Municípios não podiam continuar administrados pelos genéricos dispositivos da Constituição do Império de 25 de março de 1824 (arts. 167, 168 e 169).

Diante da realidade, os governantes daquela época só tinham um caminho, a elaboração de uma lei geral sôbre a vida municipal. Isto foi feito em data de $10^{\circ}$ de outubro de 1828 .

Esta lei trazia em seu bojo duas reformas essenciais: a eleição direta e a supressão de funções judiciárias. O processo eleitoral novo fêz cessar o antigo regime «de confirmação expressa do Govêrno» dos eleitos.

Apesar dêsses salutares preceitos da nova Lei ela não deixou os Municípios com renda suficiente, ao contrário disto, manteve como muito bem acentua Carneiro Maia a um legado ridículo das «Ordenações do Reino». $\left({ }^{4}\right)$

Abolindo tôda a jurisdição contenciosa das Câmaras Municipais, não há dúvida de que contribuiu, muito acertadamente, para dar nova paisagem à nossa vida politica e administrativa.

Dentre os vultos do municipalismo do século passado não podemos esquecer a figura consagrada de JOAQuim dE Oliveira MACHADO, autor, dentre outros, do «Manual dos Vereadores». $\left({ }^{5}\right)$ Ele foi um municipalista consciente, não apenas um mero estudioso dos problemas municipais de sua época. Êste trabalho é um repositório magnifico de estudo sôbre a criação, eleição, instalação e suspensão das Câmaras; da natureza das Câmaras; das postu-

$\left({ }^{2}\right)$ Direito Público Brasileiro e Análise da Constituição do Império, p. 316.

$\left({ }^{3}\right)$ Constituição Politica do Império do Brasil, p. 132.

(4) Obra citada, p. 190.

$\left.{ }^{5}\right)$ Manual dos Vereadores - Rio de Janeiro - B. L. Garnier, 1868. 
ras, seu objeto, sanção, sua execução e recursos; orçamento municipal, receita, sua arrecadação; despesa, sua fiscalização; arrecadação e contabilidade; fiscalização; funcionários municipais, inclusive motelos vários para petição de licença, têrmo de depósito de finanças, crimes, guia de vacinação, contra to de obras, etc.

\section{CONCEITO DE MUNICIPALIDADE DE OLIVEIRA MACHADO}

Inicialmente, JoAquim DE OlIVEIRA MAchado começa a conceituar muito genèricamente a expressão municipalismo. $\left({ }^{\circ}\right)$ «não é o sistema científico concebido e disposto pelo simples engenho do publicista nem tampouco a tradição perdida de um poder histórico já gasto e esterilizado, pela ação de passado.

Participando, pela essência de sua espécie, alguma coisa de providencial, o poder municipal tira sua razão de ser da misteriosa lei da perfectibilidade que dirige os altos destinos dos povos, no lento e pausado curso de sua longa vida.

O reconhecimento prático e gradual dos direitos de personalidade à porfia de sangrentas lutas; a natural libertação das classes servas da tirânica opressão dos nobres do feudalismo; a necessidade da concentração da fôrça do número para repelir a influência subjugadora do clero; as concessões generosas de certas franquias com que os principes premiarão os serviços do povo desta ou daquela localidade; o influxo benéfico, enfim, das idéias da igualdade, profusamente derramando sôbre a face do orbe, pelas doutrinas de Cristianismo, eis a sintese dos elementos históricos sociais, que impedirão o desenvolvimento do municipalismo nos últimos períodos da idade antiga e primeiros das subsequentes».

Passa, em seguida, a fazer uma rápida análise em tôrno da realidade brasileira, apontando alguns defeitos da lei de $1 .^{\circ}$ de outubro de 1828 e do funcionamento das Câmaras municipais, acentuando no final do seu excelente prefácio: $\left({ }^{7}\right)$ «Hoje que os raios do judicial e contencioso estão aclarados, a expensa das luzes do século, já é tempo de fazer passar a instituição municipal pelo cadinho de uma revisão acurada, sendo aferida pelos princípios e verdades que a ciência do direito público tem sabido acumular.

Já se teria se os autores da reforma adicional à nossa Constituição não houvessem entregue rendidas à discrição e algemadas nossas municipalidades às assembléias legislativas provinciais, a quem outorgaram soma excessiva de larguezas politicas com profundo sacrifício das já minguadas regalias municipais.

Tirais a tutela rigorosa imposta às Câmaras pelo ato adicional; dar-lhes movimentos mais livres no desempenho de suas funções; alargai a esfera de suas atribuições na ordem administrativa, sem contudo quebrar o vínculo da unidade politico-governamental; engrossai as fontes de suas rendas tirando

( $\left.{ }^{6}\right)$ Obra citada acima, p. 9.

( $\left.{ }^{7}\right)$ Obra citada acima, p. 13. 
ao tesouro ou à provincia aquelas que mais de perto atingem aos habitantes das localidades; traçai a linha dos serviços materiais a seu cargo com a iniciativa exclusiva de sua decretação; renovai metade de seus membros de dois em dois anos para que mais circulem as evoluções dos sentimentos populares e seja pôsto em prova o mérito de cada eleito, e a ação das Câmaras, em vez de tímida e acanhada, será enérgica e eficaz.

O municipalismo tornar-se-á a escola prática da educação politica do povo, o noviciato acessivel e elementar dos homens de estado.

A integridade nacional será assegurada em todos os ângulos do Império e a homogeneidade de civismo a partilha comum de todos os cidadãos.

Reformemos, enfim, não remendemos, exclama o ilustre «Visconde do Uruguai».

\section{O ATO ADICIONAL E OS MUNICÍPIOS}

O Ato Adicional, de 21 de agôsto de 1834, trouxe, sem dúvida, alterações legais sôbre a matéria municipal, do seguinte teor:

«Art. 10 - Compete às mesmas Assembléias legislar (referese às Assembléias Provinciais):

IV - Sôbre a polícia econômica municipal, precedendo propostas das Câmaras.

$\mathrm{V}$ - Sôbre a fixação das despesas municipais e provinciais e os impostos para elas necessários, contanto que êstes não prejudiquem as imposições gerais do Estado. As Câmaras poderão propor os meios de ocorrer às despesas dos seus municipios.»

O fato é que as Assembléias Provinciais absorvem, lamentàvelmente, os podêres dos Municípios, nessa fase histórica da vida politica brasileira.

Antônio Joaquim Ribas referindo-se ao famoso Ato Adicional em relação às Câmaras Municipais esclareceu interpretando os dispositivos dessa lei: $\left({ }^{9}\right)$ «É também certo que a sua autonomia não é completa, mas só porque se acham como que sob a tutela das assembléias provinciais quanto à fixação de suas rendas e despojos, a fiscalização delas, a decretação das providências relativas à polícia e economia municipal (Ato Ảd. art. 10 $\S \S 3^{\circ}$ a $7^{\circ}$, art. $11 \S 3^{\circ}$, e Lei de 12 de maio de 1840 arts. $1^{\circ}$ e $2^{\circ}$ ); como porque de seus atos há recurso para os presidentes de província e para o Govêrno imperial, quando a matéria fôr meramente econômica e administrativa (Lei de $10^{\circ}$ de outubro de 1828 art. 73 ).

Vicente Pereira do RÊGo, em seu livro de Direito Administrativo de 1877, estuda a história das Câmaras Municipais. Interpretando a legislação da época sôbre o assunto, assinala com certo destaque metodológico: $\left({ }^{10}\right)$

(8) Yves de Oliverra - Curso de Direito Municipal - obra citada, p. 259.

(9) Direito Administrativo Brasileiro - Rio de Janeiro - 1866 - p. 195.

$\left.{ }^{(10}\right)$ Compêndio ou Repetiçốes Escritas Sôbre os Elementos de Direito Administrativo - Recife - D. F. das NeVES GuIMARÃES - 1877, p. 89. 
«Estas atribuições são relativas aos diferentes interêsses da sociedade municipal e compreendem os direitos de regulamento, deliberação e informação.»

Continuando:

«1..$\left.^{\circ}\right)$ Há objetos que interessam só ao presente, a cujo respeito tem a Câmara Municipal o direito de regulamento, e as suas deliberações são executórias, sem aprovação expressa da autoridade superior.

2. $\left.{ }^{\circ}\right)$ Há objetos que podem interessar o futuro e alterar o patrimônio das municipalidades, e a cujo respeito tem a Câmara direito e a iniciativa de deliberação; mas as suas deliberações devem ser seguidas da sanção do Presidente e do poder legislativo provincial.

Assim é quanto aos atos que respeitam ao exercício do direito de propriedade, exceto os atos puramente administrativos, como sôbre a polícia e economia municipal, sôbre a fixação das despesas municipais, os impostos para delas necessários, e os meios de ocorrer às despesas dos municipios, sôbre o orçamento das respectivas comarcas sôbre a criação e supressão dos empregos municipais e estabelecimentos dos seus ordenados, etc. (Ato Adicional, art. $10^{\circ} \S \S 3 .^{\circ}$ e $\left.7 .^{\circ}\right)$.

Para todos êstes atos é necessária aprovação que compete aos diferentes graus da hierarquia do Estado, segundo a natureza das deliberações, cuja iniciativa é exclusivamente reservada à Câmara Municipal. Essa aprovação deve ser expressa, é o complemento necessário da deliberação; não pode, pois, ser suprimida por uma simples presunção; é enfim, uma formalidade substancial.

3. ${ }^{a}$ - Há, finalmente, objetos que interessam ao município, mas de un modo mais indireto, e então a Câmara Municipal tem apenas um direito de informação; isto é, de ser ouvida, ou uma atribuição meramente consultiva».

Citamos o texto das considerações de Vicente Pereira do RÊGo para mostrar que houve realmente, com o Ato Adicional, uma diminuição considerável de poder, outrora reservado às Câmaras Municipais no Brasil. É que, com o Ato Adicional, as Assembléias Provinciais passaram a ter competência em assuntos pertinentes às Municipalidades, tais omo sôbre desapropriação por utilidade municipal ( $\S 3 .^{a}$, do art. 10, do Ato Adicional); política e economia municipal, precedendo propostas das Câmaras $\left(\S 4 .^{\circ}\right.$, do art. 10, do Ato Adicional); fixação das despesas municipais, e os impostos para elas necessários, etc. ( $\left(5 .^{\circ}\right.$, do art. 10 do Ato Adicional); fiscalização do emprêgo das rendas municipais e das contas de sua receita e despesa ( $§$ $6 .^{\circ}$, do Ato Adicional); criação e suspensão dos encargos municipais e estabelecimentos de seus ordenados $\left(\S 7.0^{\circ}\right.$, do art. 11, do Ato Adicional); autorização para que as Câmaras Municipais pudessem contrair empréstimos (§ $30^{\circ}$, do art. 11, do Ato Adicional).

Em homenagem, muito especial, ao Visconde do Uruguai, pelo senso crítico que se manifestou no seu precioso livro - «Estudos Práticos Sôbre a Administração das Províncias no Brasil», - na parte referente ao Ato Adicional, transcrevemos abaixo, uma das mais belas páginas escritas em nosso país, de condenação ao centralismo a que levaram o regime político 
de então, com o sacrifício dos podêres que tinham as antigas Câmaras Municipais: (11) Quanto às municipalidades não as temos dignas dêsse nome. Nas grandes Provincias, sobretudo, são numerosas as municipalidades, não podem as Assembléias provinciais, ocupar-se delas sèriamente.

Ficarão as Câmaras Municipais pelo ato adicional mais peadas que antes, e à tutela em que estavam dos Presidentes de Provincia acresceu a rigorosissima das Assembléias provinciais.

Os autores do ato adicional criarão um poder provincial em cujas mãos centralizarão o municipal.

Às Assembléias provinciais compete pelo ato adicional legislar, sôbre a policia e economia municipal; legislar sôbre a fixação das despesas e impostos municipais: sôbre a criação e supressão dos empregos municipais. As Câmaras Municipais são meras pupilas.

A Assembléia provincial regula objetos puramente municipais, não pode a Assembléia Geral revogar ou alterar aí coisa alguma.

$\mathrm{O}$ ato adicional descentralizou do Poder Geral completamente, com razão, o que era puramente provincial sôbre muitos pontos.

Centralizou, porém, vigorosa e completamente nas Assembléias provinciais o que era puramente municipal.

Não temos nas Provincias verdadeiras municipalidades. Foram entregues amarradas às Assembléias provinciais.

Tem-se mêdo das Câmaras Municipais? Não se poderia com mais razão tê-lo das Assembléias provinciais? Não têm estas abusado em muito maior escala? Não têm estas muito maior campo e grande facilidade para ultrapassarem suas atribuições?

Os negócios mais ou menos importantes das municipalidades dependem ùnicamente das Assembléias provinciais.

Por que desenvolveu e alargou o ato adicional o direito consagrado no art. 71 da Constituição, ùnicamente a respeito das Assembléias provinciais e não a respeito das municipalidades? Não são as municipalidades a primeira, a menos perigosa escola de liberdade?

Tem-se querido remendar o sistema da lei de $1 .^{\circ}$ de outubro de 1828 , filha de inexperiência do seu tempo, sistema municipal completamente desvirtuado pelo ato adicional.

$\mathrm{Na}$ minha opinião o que existe hoje não admite simplesmente remendos. Exige completa reforma.

É preciso adotar a base e o sistema inglês e o americano, com certas cautelas para segurar a instituição nos seus princípios. É preciso fazer voltar para os municípios um poder que dêle tirarão e centralizarão nas capitais das Provincias nas Assembléias provinciais.

(11) Estudos Práticos sôbre a Administração das Provincias no Brasil - Tomo I Rio de Janeiro. B. L. Garnier. 1865, p. VIII. 
É preciso fixar e definir bem o que é puramente municipal, e sòmente pode prejudicar os munícipes.

$\mathrm{O}$ ato adicional matou, como veremos, as liberdades municipais. Que liberalismo! Que progresso!

Temos tido e temos por aí muitas municipalidades que têm administrado e administração pèssimamente os seus municipios, apesar de o fazerem debaixo da direção absoluta das Assembléias provinciais. E como têm dirigido algumas Assembléias os seus próprios negócios e os das municipalidades? Deploràvelmente.

Os males que deploramos podem vir das municipalidades. Também das Assembléias provinciais.

Aprenda cada um com o que lhe diz respeito de perto; e especialmente o responsabiliza.

Se voltássemos para o antigo poder, estariamos em muito pior estado. Divida-se o poder e a responsabilidade.

$\mathrm{O}$ ato adicional descentralizou o poder provincial do geral. Assim convém a muitos respeitos. Centralizou o poder municipal nas Assembléias provinciais. O poder geral não trata de negócios provinciais e dos municipais. O poder chamado municipal não é poder entre nós.

\section{geral. \\ A liberdade política é tôda uma só, única para todo o Império. É a lei}

Liberdade política provincial? O que é liberdade política provincial? Em que difere liberdade politica de uma Provincia da de outra? A Provincia não é uma divisão politica, mas administrativa. E as liberdades municipais, onde estão elas entre nós? $\mathrm{O}$ ato adicional matou-as.

Entretanto nenhhum povo pode ser livre sem instituições livres municipais. Que o digam a Inglaterra e os Estados Unidos.

O Ato Adicional não deu ao País aquilo de que necessitava. Não conteve o seu espírito municipal, informador de nossa formação histórica e politica, fazendo predominar, sem razão, um centralismo administrativo absorvente e condenável, mesmo que tenha ajudado a fortalecer as Provincias num momento realmente em que estas precisavam de encontrar a sua justa posição política e administrativa.

\section{A CONSTITUIÇÃO REPUBLICANA DE 1891}

Com a República no Brasil, em 15 de novembro de 1889 , outra organização foi dada aos municípios mais consentânea com as suas funções; mais autônomos ficaram e com melhor delineamento legal as suas atribuições.

O projeto do Govêrno Provisório estava assim redigido: $\left({ }^{12}\right)$

«Art. 67. Os Estados organizar-se-ão por lei suas, sob o regime municipal, com estas bases:

$1 .{ }^{\circ}$ ) autonomia do município, em tudo quanto respeita ao seu peculiar interêsse:

$2 .^{\circ}$ ) eletividade da administração local.

(12) Obras Completas de Ruy Barbosa - A Constituição de 1891; p. 91. 
Parágrafo único - Uma lei do congresso organizará o município do Distrito Federal.»

O texto definitivo da Constituição Federal de 1891, ficou com a redação seguinte:

«Art. 68. Os Estados organizar-se-ão de forma que fique assegurada a autonomia dos municípios em tudo quanto respeite ao seu peculiar interêsse.»

Ar.fredo Varela declara que: (13) «O federalismo é, desde 1831, a mais ardente e mais generalizada aspiração do Brasil.»

\section{A CONSTITUIÇÃO FEDERAL DE 1934}

A Constituição Brasileira de 1934 alterou para melhor, inegàvelmente, o dispositivo do art. 68 da Constituição de 1891, ficando com a redação seguinte:

Art. 13 - Os municípios serão organizados de forma que lhes fique assegurada a autonomia em tudo que respeite ao seu peculiar interêsse, e especialmente:

I - à eletividade do Prefeito e dos Vereadores da Câmara Municipal, podendo aquêle ser eleito por esta;

II - à decretação dos seus impostos e taxas e arrecadação e aplicação das suas rendas;

III - à organização dos serviços de sua competência .

$\S 10^{\circ}$ - O Prefeito poderá ser de nomeação do govêrno do Estado no Municipio da Capital e nas estâncias hidrominerais.

Inovou a Constituição Brasileira de 1934 também quanto às fontes de renda dos municípios estabelecendo de forma clara, quais os impostos e taxas que competiam aos mesmos, assim enumerado:

$\S 20^{\circ}$ - Além daqueles de que participam ex-vi do art. 8, $\S 2 .^{\circ}, 10$, parágrafo único e dos que lhe forem transferidos pelo Estado, competem aos Municípios:

I - O impôsto sôbre licenças;

II - os impostos predial e territorial urbanos cobrados sob a forma de décima ou de cédula de renda;

III - o impôsto sôbre diversões públicas;

IV - o impôsto cedular sôbre a renda de imóveis rurais;

$\mathrm{V}$ - as taxas sôbre serviços municipais.

${ }^{(13)}$ Direito Constitucional Brasileiro - 1902, p. 41. 


\section{A NOVA FASE DO MUNICIPALISMO BRASILEIRO}

\section{A Constituição Brasileira de 1946}

Com a Constituição Brasileira de 1946 surgiu a nova fase do municipalismo. O conceito de federação sofreu o seu mais veemente impacto. Elevando o Municipio na atual Constituição Brasileira à mesma categoria institucional que a União e os Estados-Membros, alterou-se a fisionomia, em igualdade de situação jurídica das demais esferas de Govêrno, no que diz respeito à competência política, administrativa e financeira. Entre os princípios constitucionais da União, conforme prescreve o art. $7 .^{\circ}, \mathrm{n}^{\circ}$ VII, letra e, figura o principio da autonomia municipal. Assim, uma nova feição to. mou o regime político-constitucional brasileiro com a Carta Magna de 1946, de sentido nitidamente municipalista, consubstanciada em uma descentralização politica e administrativa em três graus, e não em dois como era de nossa tradição federalista.

O art. 28 da atual Constituição Brasileira prescreve:

Art. 28. A autonomia dos Municípios será assegurada:

I - pela eleição de Prefeito e dos Vereadores;

II - pela administração própria, no que concerne ao seu peculiar interêsse e, especialmente:

a) à decretação e arrecadação dos tributos de sua competência e à aplicação das suas rendas;

b) à organização dos serviços públicos locais.

\section{Tributos Municipais}

O art. 29 da Constituição brasileira de 1946 está assim redigido:

Art. 29 - Além da renda que lhes é atribuída por fôrça dos parágrafo $2 .^{\circ}$ e $4^{\circ}$ do art. 15 , e dos impostos que, no todo ou em parte, lhes forem transferidos pelo Estado, pertencem aos Municipios os impostos:

I - Predial territorial urbano;

II - De licença;

III - De indústrias e profissões;

IV - Sôbre diversões e profissões;

V - Sôbre atos de sua economia ou assuntos de sua competência.

A referência aos parágrafos $2 .^{\circ}$ e $4^{\circ}$ do art. $15 \mathrm{diz}$ respeito aos impostos sôbre combustiveis e sôbre impôsto de renda.

Um dos pontos básicos do regime politico brasileiro é o da autonomia financeira dos municipios, no que respeita à decretação e arrecadação dos tributos de sua competência e à aplicação das suas rendas.

\section{$10 \%$ do Impôsto de Renda}

O $\S 4 .^{\circ}$ do art. 15 , da mesma Constituição, destinou $10 \%$ do impôsto de renda, tributo de caráter nacional, aos Municípios, a fim de melhorarem as suas fontes de receita. 


\section{$30 \%$ de Excesso de Arrecadação dos Estados}

$\mathrm{O}$ art. 20 dessa Carta Política inseriu a obrigação de os Estados-membros entregarem aos Municipios também 30\% do excesso de arrecadação. Este preceito, lamentàvelmente, ainda não é cumprido por uma minoria de governadores de Estado.

Enquanto isto, a emenda constitucional n..$^{\circ} 1$ encontra-se no Parlamento Nacional, alterando para melhor a discriminação de rendas do País, em favor dos Municipios brasileiros.

\section{DESCENTRALIZAÇÃO E ESPIRITUALIZAÇÃO DO ESTADO MODERNO}

A descentralização e a espiritualização do estado moderno são o consectário da vida hodierna. O Estado centralista não suporta mais o ônus de suas funções fechadas a determinadas zonas de influência e de civilização, ditando ordens e a tudo querendo subordinar, no seu afã de comando absorvente. Não. O Estado moderno se descentraliza, sem perder, contudo, a sua unidade de ação soberana, ou muito restará fazer contra a sua absorção de podêres, pelos homens e comunidades distantes de sua influência imediata e longe de seu alcance político e administrativo, social e humano.

Por sua vez, o conceito espiritualista da vida ganha consagração sem deixar o homem de valorizar o aspecto material dos fenômenos, na proporção em que êsse aspecto material possa contribuir para a sua espiritualidade e felicidade, portanto. O Município é uma entidade política da sociedade local, segundo a escola sociológica de Carmona Romay, Ahrens, Azcárate, Giner, Savigny, Hostos, Carrera, Jùstiz, Capablanca e outros. Êstes conceitos da єscola sociológica caracteriza-se: a) pela eleição democrática dos governantes; b) pelo Home rule, isto é, pela autonomia municipal em função do Estado; c) pela personalidade jurídica própria; d) pelo contrôle judicial sôbre órgãos e atos.

\section{SUPERAÇÃO DO CONCEITO DE FEDERAC̣ÃO}

Em nosso país, o conceito de federação está superado, ou, no mínimo, reformado. Bem sabemos das dificuldades dos autores em conceituar o que seja Federação. Todavia, pretendemos situá-lo numa média de opiniões e tendências, como sendo: a descentralização politica e administrativa em dois graus. Reparai bem, «em dois graus»: a União e os Estados Membros. Isto é a Federação, no seu conceito mais ou menos exato. E o Municipio onde fica, nessa Federação? Como acentua CAstro Nunes, êste é unitário em relação aos Estados membros. Na Federação tal qual se nos afigura dentro do conceito da ciência, o Município não aparece como entidade em detalhe, na organização política e administrativa do País, isto é, na sua Carta Magna. Veja-se, por exemplo, na Constituição da Argentina e na de outros países.

No Brasil, assistimos à sua Constituição Nacional de 1946 incluir até - Município entre os princípios constitucionais da União! Isto é a mais aberrante deturpação do conceito de Federação! O que há no atual regime constitucional brasileiro é uma descentralização em têrmos absolutos, do concei- 
to de federação, completando-se uma descentralização do Estado moderno ao máximo. Como quer que seja, na vida hodierna, o Municipio readquire o seu prestígio e determina um conceito de vida que não o desconheça, mas, pelo contrário, o exalte, com o seu próprio fundamento, dentro da civilização moderna, e de acôrdo com as justas aspirações das coletividades.

\section{A REPÚBLICA MUNICIPALISTA}

O que precisamos é assentar em têrmos definitivos, positivos de doutrina e de Direito, a superação daquele conceito de federação, avançando-se numa caracterização político-constitucional do Brasil, descentralizada em três graus: União (Nação), Estados-Membros e Municipios, a fim de configurarmos uma nova definição do Estado. Marchamos, sim, para uma República Municipalista. Êste é o nosso caminho... Procuraremos unir os nossos propósitos doutrinários, com elevação, senso de oportunidade e coesão de pensamento, sem o que tudo ficará no sonho ou na utopia. Não recuaremos, entretanto, diante das dificuldades de nossa caminhada, porque até agora parece havermos conseguido vencer as primeiras e mais difíceis resistências encontradas, com ânimo forte, energia criadora e tolerância.

\section{CONCEITO ATUAL DE MUNiCIPALISMO}

1. A doutrina municipalista impregna, na sua filosofia, um conteúdo eminentemente valorizador do homem, sem distinções regionais e econômicas, financeiras, raciais, climatéricas, sociológias ou psicológicas, éticas ou morais. Procura corrigir as desigualdades humanas, fruto da inoperância e da falta de consciência racional na distribuição da riqueza da terra e das condições geográficas. Essa é a nossa meta filosófica. Êsse o nosso rumo çientífico, dando ao homem, onde quer que êle esteja, um minimo de condições de civilização moderna, através da solução dos problemas de base, principalmente os de transportes, energia elétrica e educação.

Outorgando ao homem tais condições de civilização moderna, em têrmos não só individuais, mas comunitários, também, através de soluções coletivas, possibilitaremos vida melhor para cada individuo e cada agrupamento social. Não separamos, nem isolamos as soluções individuais das soluções coletivas, das comunidades pròpriamente ditas, nem permitiremos que predomine o atual e chocante contraste entre as regiões geogràficamente consideradas, que apresentam como hoje em dia num mesmo momento da história da humanidade, paisagens diferenciadas no campo do progresso e da técnica.

Que haja diferenças regionais; nunca, entretanto, tão intensas e tão absurdas como as que assistimos, com os nossos olhos perplexos e estarrecidos, testemunhando o modo contrastante por que estão vivendo homens e povos, em estágios muitas vêzes diversos de civilização, numa mesma hora e num mesmo instante...

Se tivermos contribuído, com nossa parcela de esforços, para corrigir essa desigualdade, que não é só individual, mas profundamente coletiva, não há dúvida de que estaremos tranqüilos com a nossa consciência e recompen- 
sados com as incompreensões. Não lutaremos por posições político-partidárias, dentro da rigidez dêsses conceitos; outrossim, pelo homem universlamente falando, pela humanidade geogràficamente considerada e pelo nosso País, contra as desigualdades existentes entre as suas comunidades, aber rantes desigualdades, essas, comprobatórias de erros e de equívocos doutrinários e filosóficos.

Eis ai um dos objetivos da doutrina municipalista, que amanhã substituirá, num futuro determinado, as obsoletas teorias ainda existentes e que deveriam já estar mumificadas no arquivo da história ou num museu de antiguidades por outras mais consentâneas com o grau de civilização que já atingimos. Não podemos admitir que se fale mais ao homem com promessas de um frio lirismo politico, consubstanciado na chamada e hipotética igualdade de todos perante a lei. A igualdade de todos perante a lei só se pode dar com a possibilidade de se dar também a cada indivíduo idêntica oportunidade de usar e obter os instrumentos de civilização moderna. Essa igualdade teórica já se pode constituir um tema ultrapassado para os dias em que vivemos.

O homem tem que conciliar os elementos espirituais com os meios materiais, fruto da técnica e do industrialismo modernos. Sem essa conciliação, num mundo demogràficamente denso, profundamente concorrente, saturado de privilégios e de injustiças, não será possível mais ao homem viver sem uma melhor distribuição da riqueza da terra e sem o seu racional aproveitamento em nome de uma concepção de vida filosòficamente mais igualitária e tècnicamente mais racionalizada, que não esqueça os direitos do indivíduo nem negue o bem-estar coletivo de tôdas as comunidades ao mesmo tempo.

Não basta dar ao homem, em determinado lugar, o privilégio de poder usar os instrumentos de técnica moderna; é preciso mais do que isto: dar a todos um mínimo de condições de vida que não incorra numa desigualdade injustificável, revoltante a tôda prova.

Esse ideal municipalista marcha acompanhando tanto o desenvolvimento técnico e industrial do mundo atual, quanto também o clima de desigualdades e de injustiças entre os homens e entre as comunidades ou agrupamentos sociais. Corrigir essas diferenças, lutar pelo aplainamento adequado dêsses contrastes humanos e sociais, constitui a meta fundamental e o sentido teleológico da doutrina municipalista.

\section{CONCEITO DE SUPERMUNICIPALISMO}

2. Dar-se a cada homem e a cada comunidade um minimo de condições de civilização moderna é o objetivo fundamental da doutrina municipalista, proporcionar a cada individuo e a cada comunidade o máximo de condiçóes de civilização moderna, configura-se o que nós chamamos de supermunicipalismo.

Teria alguém definido o que seja supermunicipalismo e firmado o seu conceito em têrmos científicos? Ou estamos criando ou definindo algo que 
não passaria de uma tentativa frustrada, desde os primeiros instantes? Ou será que a nossa convicção cientifica poderá algum dia realmente representar uma conceituação exata dessa expressão no mundo da ciência?

O que poderíamos recear é a falta de conceituação doutrinária dessa expressão. Todavia, não temernos o sorriso dos irônicos, nem aceitamos tranqüilos os aplausos dos adesistas. Desejamos antes e acima e tudo, nêste século da energia e da velocidade, e também do realismo e da positividade, não perder tempo, ou ficar envolvidos pelos preconceitos filosóficos e doutrinários revelados até o momento.

Para chegarmos ao Supermunicipalismo, temos de partir do conceito de Municipalismo. Não se pode compreender uma expressão sem conceituar a outra. O Municipalismo visa, no sentido filosófico, dar a cada Homem e cada Comunidade um minimo de civilização moderna, no mesmo instante na história da humanidade. Acabar-se com esta desigualdade de tratamento social e humano, no seu conjunto filosófico, eis o fim mais profundo dessa doutrina. Como conseguirmos êsse objetivo? Tirando-se de estágios primitivos, atrasados, em condições mais precárias de civilização muitos agrupamentos sociais e dando-lhes tôdas as condições minimas de progresso e desenvol vimento. Assim teríamos alcançado o objetivo inicial, que seria proporcionar a cada homem e a cada Comunidade um minimo de condições de civilização moderna.

$\mathrm{E}$ o máximo? $\mathrm{E}$ as áreas sociais que tivessem alcançado o grau máximo de civilização? E o Homem que tivesse podido superar o seu semelhante com uma concepção pragmática da vida a mais perfeita, na sua profundidade humana, psicológica, estética, social e ética? Como poderíamos situar o Homem e tais Comunidades que chegassem ao grau mais alto e mais progressista da convivência social? Um índice de civilização que permitisse, por exemplo, a utilização, pelo Homem, de consumo de energia elétrica por habitante de $1.000 \mathrm{kw}$., outro que permitisse o consumo individual de $10.000 \mathrm{kw}$ ? Nesse último caso, o Homem talvez tenha alcançado o grau máximo da civilização moderna, usando os fatôres de progresso e desenvolvimento material, intelectual e moral em condições as mais perfeitas e adequadas. Encontramos ai o fundamento do conceito de Supermunicipalismo.

A civilização supermunicipalista será a civilização da era atômica! Será a civilização na qual o Homem e as Comunidades se elevarão ao grau máximo de perfeição humana, no progresso técnico, no desenvolvimento industrial, na estética, na ética e na adequação moral. Será que a inteligência do Homem permitirá uma era de igualdade consciente, de igualdade nascida da espontaneidade, de igualdade sonhadora, a mais bela e risonha imaginada pelo amor ao próximo como a si mesmo? Essa igualdade, fundada numa distribuição perfeita da energia atômica, equivalente a três milhões de vêzes à do carvão mineral e a dois milhões à do petróleo, promanadas do urânio e do tório, é a inspiradora, em nossa fraca inteligência, da concepção do Supermunicipalismo: ideal supremo e sublime da grandeza humana e da perfeição social.

Se a humanidade não puder chegar a essa etapa superior de civilização, pelo menos sonhamos, num dia de lucidez, de esperanças e de idealismo, com êsse sublime desiderato. 


\section{O MÉTODO MUNICIPALISTA DE PESQUISA - o ESTATÍSTICO}

3. Os conceitos, ora emitidos, assinalam talvez uma linha de separação entre a fase pioneira, pròpriamente dita, do Movimento Municipalista e a fase atual em que estamos vivendo, de uma doutrina consolidada pelo seu sentido filosófico e pelo seu método de pesquisa, que é o estatístico. Não estamos encarando a vitória dêsse Movimento pelas manifestações exteriores de aplausos convencionais, fruto das possibilidades materiais de propaganda, incentivo ou difusão. Não. Êsse aspecto, embora muito importante, para nós, é, nesse instante, secundário, ante a reflexão profunda dos fundamentos científicos da doutrina municipalista. O que ela vale pelo seu conteúdo doutrinário e o que encerra pelo seu colorido filosófico são os aspectos mais transcendentes e mais importantes dos dias atuais, em razão do tempo, e do espaço, dos homens e das coisas, da teoria e dos seus resultados práticos. Ai é que está a razão suprema de nossas lutas e dos nossos sofrimentos, de nossas vitórias e de nossas incompreensões! Ai é que está o fundamento perene dessa jornada de sonhos maravilhosos e dessa caminhada que parecia utópica! Aí é que está o prisma consagrador da longa peregrinação pelas fantasias do espirito e pelas indagações sociológicas.

Não temos a veleidade de fazer afirmações dogmáticas sôbre a matéria tratada. Procuramos, sim, situá-las com espírito científico e clareza de objetivos pragmáticos, em benefício do Homem e das Comunidades. Visamos, por outro lado, a solução de fundamentais problemas humanos e coletivos que têm desafiado a inteligência e as condições mais indicadas de adaptação do Homem ao ambiente social em que vive.

O Municipalismo talvez seja o melhor caminho, o caminho mais indicado, pelo seu conteúdo filosófico e pelo seu método de pesquisa. Sem a ajuda de homens de boa vontade e de estudiosos mais indicados, não poderão ser analisadas e completadas as idéias aqui consideradas.

\section{ETAPAS IMPORTANTES PARA O MUNICIPALISMO}

4. O Movimento Municipalista marcha dentro dos planos estabelecidos pelos lideres. Há sempre em todos os Movimentos os idealizadores, os seus pioneiros e os seus consolidadores. Por isso o passo fundamental para qualquer jornada doutrinária é dar-lhe sentido filosófico e objetividade cientifica. Naturalmente isto é o mais difícil, contudo, o mais permanente e - mais profundo. Um Movimento doutrinário sem filosofia acaba no personalismo de seus lideres, desaparecendo com o tempo, em vez de alcançar um proselitismo substancial, ou um conteúdo ideológico adequado.

A história dos acontecimentos políticos e doutrinários do mundo está a nos ensinar que o caminho de uma boa liderança é sempre o mais difícil. O que mais requer são individualidades à altura dêsses altos e elevados propósitos científicos e sociais. O Movimento Municipalista não ficará no papel, nas Cartas de Municipios oriundos dos congressos realizados nem na cabeça idealista de muitos de seus lideres. Êle tem que se projetar objetivamente, de evoluir dentro de certas normas preestabelecidas, examinando-se, de vez em quando, as metas alcançadas, as suas vitórias e os seus erros, os seus pensamentos doutrinários e a realidade social objetivamente considerada. 
Êsse exame de consciência na evolução do Movimento Municipalista talvez tenha o seu ponto culminante nos dias atuais em que o mesmo vive, naturalmente, dentro dessa primeira etapa de consideração filosófica e doutrinária. Por isso a nossa preocupação é grande: não por causa de influências pessimistas, mas pela evolução mesma da doutrina municipalista, que alcançou um grau considerável, em tão pouco tempo. Desejamos, por isso mesmo, não deixar que a sua evolução prossiga sem os exames e reexames, as consultas constantes com os companheiros e as trocas de informações permanentes. Temos metas difíceis em nossa frente, metas perigosas e merecedoras de especial estudo. Com o Movimento Municipalista, não visamos alcançar um pôsto ou uma função pública à custa do engôdo ou da mentira, da falsa doutrinação ou do sofisma da inteligência. Não. Mais altos são os nossos propósitos, os valorizadores do Homem e das Comunidades, onde quer que êle ou elas estejam, dando-lhes as melhores condições de civilização moderna.

\section{PROGRAMA DOUTRINÁRIO DO MUNICIPALISMO AMERICANO}

Ao completar vinte anos de inauguração da I Reunião do Congresso Interamericano de Municipios, bem assim dez anos de lançamento do $\mathrm{Ma}$ nifesto conjunto com Alcides GreCA, que intitulamos «Postulados do Municipalismo Americano», depois de examinar a evolução e a realidade doutrinária, politica e científica do Municipalismo em nosso Continente, numa modesta contribuição para se estabelecer, de forma definitiva, um roteiro geral das idéias fundamentais dêsse Movimento, elaboramos e divulgamos, como fase complementar das considerações anteriores no VII Congresso Interamericano de Municípios, o «Programa Doutrinário de Municipalismo Americano», fonte inspiradora de uma filosofia de vida valorizadora de cada Homem e de cada Comunidade, dando-lhes um mínimo de condições de ci- vilização moderna, no mesmo momento histórico.

\section{Considera:}

\section{Aspecto Filosófico}

1) A luta dos Municípios por uma filosofia de vida alicerçada no equilibrio econômico, político, social e ético dos grupos sociais, e das Comunidades.

2) A prática da teoria da intermunicipalidade Universal, defendida por Ruy DE Lugo VIÑA e em virtude da qual se torna extensivo aos Municipios o direito de cooperação internacional, como já vem acontecendo com a Comissão Pan-americana da Cooperação Internacional e o Instituto Interamericano de História Municipal e Institucional.

\section{Visa:}

\section{Aspecto Politico e Constitucional}

1. ${ }^{\circ}$ A implantação em cada País da América da República Municipalista, baseada na descentralização politica e administrativa, em três esferas do govêrno: a União, os Estados-Membros ou Provincias, e os municipios 
(teoria do Estado Municipalista), a moldes do que ocorre com o Rio Grande do Sul, no Brasil, desde 1891.

2. ${ }^{\circ}$ A extensão, aos vereadores, da prerrogativa da imunidade que é: outorgada aos deputados e senadores.

\section{Aspecto Administrativo}

Objetiva:

$\left.1 .^{\circ}\right)$ Solução dos problemas de base e regionais do País, destacadamente os de transporte, energia elétrica e educação, visando o fortalecimento econômico da vida local.

$2 .^{\circ}$ ) Descentralização administrativa dos serviços de assistência e previdência tendo- em vista faciliatr o contato entre a instituição e o segurado, garantindo maior rapidez na concessão dos benefícios.

3. ) Elaboração de Códigos Municipais em cada Comuna, visando dar unidade às Leis locais, condensando quanto possivel, em um só corpo legislativo, a matéria municipal.

$\left.4 .^{\circ}\right)$ Instituição do sistema de recrutamento para o serviço público pelo critério do mérito, não bastante porém, tão só selecionar, e sim também orientar e proceder a uma revisão periódica, devendo-se ressaltar a contribuição da psicotécnica para êste importante e fundamental objetivo.

\section{Aspecto Econômico}

Tem por objetivo:

$\left.10^{\circ}\right)$ Valorização dos planejamentos urbanos, rurais e regionais, dando-se ênfase administrativa aos problemas intermunicipais de base: transportes, energia elétrica e educação.

2. ${ }^{\circ}$ Cobrança de uma taxa de planejamento, nos Municípios, para elaboração dos planos e projetos do govêrno local.

3. ) Instalação sôbre a forma cooperativa, de bancos regionais, destinados a servir de base a um futuro instituto de crédito municipal.

4. ) Cooperação entre os Municípios, para criação de sociedades de fins econômicos, quando a execução dos acôrdos intermunicipais o tornar necessário, podendo participar do empreendimento pessoas físicas ou jurídicas.

5.') Apoio à reforma agrária que deverá realizar-se através da cooperação e do esfôrço conjugados dos três niveis de govêrno.

6. ) Incentivo à criação de Bancos dos Municipios, com o fim de reter no interior as fortunas ali formadas.

7. ${ }^{\circ}$ Participação efetiva dos Estados-Membros ou Províncias e Municipios nos lucros resultantes da exploração, industrialização e prospecção petroliferas, no respectivo território; o que é reconhecido de absoluta conveniência. 


\section{Aspecto Financeiro}

Pretende:

1.) A reforma das Constituições dos países americanos no sentido que se objetivem novas e específicas discriminações de rendas, visando o melhoramento das condições financeiras dos Municipios, terminando-se, de uma vez por tôdas, com o sistema de carência da renda pública municipal para a satisfação das funções da vida local.

$\left.2^{\circ}{ }^{\circ}\right)$ A instituição do Código Tributário Nacional, como medida indispensável à consolidação das esferas governamentais através de nitida delimitação dos campos de competência e de obediência às diretrizes básicas de uma política tributária definida em plano nacional.

3..$^{\circ}$ A percepção de quarenta por cento pelos Municipios, do total das rendas públicas arrecadadas no País, dentro em prazo razoável e de modo progressivo, mediante outorga de novos tributos.

\section{Aspecto Educacional}

Resolve:

$1^{\circ}$ ) Considerar a educação um problema de base capaz de ajudar a solucionar a crise americana, acabando-se com o analfabetismo.

$\left.2^{\circ}{ }^{\circ}\right)$ Elaborar-se um plano geral do ensino rural, com a colaboração dos Municipios e de instituições interessadas no fomento agrícola.

$\left.3^{\circ}\right)$ Intensificar o ensino profissional no interior americano.

$4^{\circ}$ ) Propagar o ensino técnico, instalando-se os respectivos cursos ao lado de cada Ginásio do Interior, segundo o plano dos Centros Regionais de Educação.

$\left.5 .^{\circ}\right)$ Valorizar o espírito universitário com o propósito de se encontrar uma filosofia de vida que torne mais feliz o homem e mais prósperas as comunidades, através principalmente da pesquisa, da investigação e da análise.

\section{Aspecto Científico e Didático}

Insiste:

1. ${ }^{\circ}$ Considerar-se o Municipalismo uma ciência municipal autônoma, com metodologia própria.

$2^{\circ}$ ) Incorporação aos planos de estudos por parte das Faculdades de Direito e Ciências Econômicas do Continenta da disciplina denominada: «Direito, Ciência, Administração e Govêrno Municipais».

3. ) Criação de institutos de altos estudos para peritos em admin.stralção municipal e urbanistas.

$\left.4 .^{\circ}\right)$ Instituição sistemática em cada núcleo urbano de um plano de urbanismo.

5..$^{\circ}$ O ensino nas escolas primárias de noções sôbre a doutrina municipalista, valorizando-se os problemas locais. 


\section{Aspecto Sanitário}

Adota:

1. ${ }^{\circ}$ A resolução dos problemas de saúde pública, paralelamente com os de assistência social, não adiantando estudar um sem pensar no outro.

2. ${ }^{\circ}$ Elaboração de um plano geral referente aos serviços de suprimento de água e às rêdes coletoras em tôdas as localidades americanas.

3. ${ }^{\circ}$ Assistência hospitalar em todos os Municipios devendo o Serviço de saúde do interior seguir uma orientação de medicina preventiva, de higiene, de profilaxia e de assistência pròpriamente dita.

\section{Aspcto Estatistico}

Tenciona:

$\left.1 .^{\circ}\right)$ Dar ênfase aos estudos estatísticos e relêvo às repartições especializadas dêsse gênero existentes nos paises americanos, como fonte inspiradora de pesquisa e de análise dos fenômenos sociais.

\section{Aspecto Judiciário}

Tem em mira:

1. ${ }^{\circ}$ Maior unidade e prestigio para o Poder Judiciário.

2. ) Representação dos Estados-Membros ou Provincias no Supremo Tribunal de Justiça de cada País.

3. ) Estimulo aos magistrados do País incentivando-os ao estudo e aprimoramento das qualidades de cultura e as inerentes à técnica de julgar, influenciando doutrinàriamente os seus julgados no sentido do fortalecimento da vida local.

\section{Aspecto Internacional}

Recomenda:

$\left.1 .{ }^{\circ}\right)$ A manutenção de meios de cooperação municipal com as entidades dos países americanos e internacionais que se dedicam ao estudo e defesa dos problemas locais, valorizando-se o princípio de Intermunicipalidade Universal de RUY DE LUGo VIÑA, ao lado da execução dos postulados contidos nas Cartas de Recomendação dos Congressso Interamericanos e Internacionais de Municipios.

Tem por objetivo:

\section{Aspecto Moral e Etico}

$\left.1 .{ }^{\circ}\right)$ Que o povo americano repudie e despreze a demagogia "politica», - voto inconsciente, a ausência de espírito público, a desonestidade pessoal e a falta de caráter daqueles que têm parcela de direção na causa pública, visando-se com isso o bem comum, a segurança e a justiça em nome de uma melhor politica democrática e de mais aprimorada educação cívica.

Pensamos, salvo melhor entendimento, que estas idéias constituem o fundamento da doutrina municipalista moderna. 